\title{
GOOD CORPORATE GOVERNANCE HELPS COMPANIES SURVIVE IN THE MIDST OF GLOBAL ECONOMIC
}

Global economic is one of the processes in economic and trade activity which is there are many countries in the world become one market power without any constraints and territorial boundaries of the country. Various types of companies and industrial sector should to be able to adapt and survive in the face of many circumstances and uncertainties in the global economy. Indonesia's companies are also innovating in business transformation, so that the companies be able to survive in the global economic vortex which tends to be sluggish but on the other side it is also followed by intense competition in the trade market. In the 2020 era until now, the global economic has experienced various problems due to impact of the Covid19 pandemic, situation and condition like this era is one of the reasons why companies are required to innovate, make reforms in many aspects, optimize production strategies and also implement good corporate governance to help companies survive in the midst of the vortex and uncertainty in the global economic market.

Good Corporate Governance or GCG is considered a concept, principles and also the rules that can be used by companies to optimize vision \& mission through a good strategy and aims to guide the company in generating added value over a long period of time, GCG is not only applied by the company but also can be applied by the government, for example by issuing economic regulations based on the principles of Good Corporate Governance (Indonesia et al., 2018). The implementation of good corporate governance will also provide many benefits to companies such a disclosure of information, an effective audit system to risk control, through the implementation of quality good corporate governance, which provides opportunities of added value for sustainable business success and also for stakeholders (Tayibnapis et al., 2019). Several companies in Indonesia that apply good corporate governance principles generally apply 5 principles of accountability, responsibility, fairness, independence and transparency in company performance \& evaluation. The GCG guidelines issued by the National Governance Committee $(\mathrm{KNKG})$ are transparency in which companies are required to provide adequate, timely and accessible information to stakeholders. Furthermore, there is Accountability which requires the companies to be accountable for all its their performance in a transparent manner, 
the companies must pay attention and manage \& direct the performance of the company, especially matters related to the interests of stakeholders. In the principle of Responsibility, the company must follow all the rules \& regulations in creating stable conditions for the companies and long-term business interests. The principle of Independence explained that the companies must be managed professionally because it will be affect every interest and also keep the companies from the influence of intervention by external parties. The last one is the Fairness principle which requires companies to pay attention to the various rights \& authorities of stakeholders fairly (Indonesia et al., 2018).

The competitiveness of the majority of companies in Indonesia against various economic disruption in the 4.0 industrial revolution is also influenced by the company's ability to take advantage of change especially in technological progress which is one of the important factors for companies to survive, develop and provide added value for stakeholders. Companies are also required to be able to predict future conditions in order to be able to implement company's strategies appropriately. Of course, there are various problems that will arise in implementing corporate strategy reforms such as matters related to organizational structure, business process and competence $\&$ transformation of human resources. Transformation in a company can be done not only in the aspects of human resources, but also in aspects of management systems, strategies, information systems, funding and other innovative ideas. In implementing the corporate transformation process the companies can by applying the basic principles of good corporate governance which include accountability, responsibility independent, fairness and transparency (Tayibnapis et al., 2019).

Good corporate governance helps Indonesia's companies survive in the midst of the global economics as evidenced by companies that have implemented GCG which is proven to be able to carry out various strategies to optimize the company's management system and show significant progress. The implementation of good corporate governance is also considered capable of encouraging companies to innovate at various aspects that encourage increased company performance, such as through product innovation, company operations and service. In fact, the existence of a system for implementing sustainable good corporate governance also has a positive impact on the capital market which is has a positive impact for business and increases the confidence of investors and stakeholders (Tayibnapis et al., 2019). 


\section{REFERENCES}

Indonesia, U. I., Garbo, A., \& Wulandari, D. A. (2018). The implementation of good corporate governance in the Aerofood ACS Company of Yogyakarta. Journal of Islamic Lariba, 4, 47-56.

Tayibnapis, A. Z., E. Wuryaningsih, L., \& Gora, R. (2019). Companies in Indonesia in the vortex of global economic disruption. 308(Insyma), 174-177.

https://doi.org/10.2991/insyma-19.2019.45 